\title{
Illocutionary Acts in Online Airline Advertising Slogans
}

\author{
Isnain Arrosid *, Aris Munandar \\ Universitas Gadjah Mada, Indonesia \\ *Email: Isnain.arrosid@yahoo.com
}

\begin{abstract}
A B S T R A C T
This research attempts to examine the illocutionary acts used in airline slogans taken from online airlines advertisements and investigate the most dominant illocutionary acts used in the slogans. The data were collected from online advertisements from November 2015 until January 2016. The results of the research show that four types of illocutionary acts are used in the slogans: directives, expressives, commissives and assertives with three patterns of illocutionary acts: Assertives entailing expressives, commissives entailing expressives and directives entailing expressives. Based on the findings, the most dominant type of illocutionary acts used was assertives with 40 occurrences (70\%). Claiming is an assertive illocutionary act that was used most frequently in the slogans. This is in line with the main aim of advertising, i.e., persuading people. No declarative illocutionary act was found in the slogans since it is hard to fill the mode of achievement of a declarative in online advertising which changes the hearer's status.
\end{abstract}

Keywords: airline advertisement, illocutionary acts, types, patterns, slogans,.

\section{INTRODUCTION}

Language has a significant role in an advertisement. The language an advertisement uses can determine whether people will buy or use the advertised product. It is supported by the competition of selling a product among companies that has been very strict. Therefore, the use of language in company advertisement slogan becomes a crucial aspect since a slogan represents a particular product. In other words, the language of a slogan is the image and identity of a company which cannot be used by other companies. The language of a slogan should have a special characteristic that differs from other companies.

Aiming to inform and to persuade people to use company products and service, the advertiser should write an easily understood slogan. In order to do so, the company has to deal with Pragmatics, especially Speech Acts. A speech act in linguistics and the philosophy of language is an utterance that has performative function in language and communication (Searle, 1969, p. 2). It will help the advertiser to figure out how the language can be used to convey the message, so the message of the advertisement can be received well by the readers.

One type of advertising is airline advertising. It is divided into two types; traditional advertising and online advertising (Janoschka, 2004, p. 18). Airline advertising also has many forms of airline advertisements with various compositions of language (slogan, description, etc.), image, and other elements of advertising.

In this research, the researcher focuses on the illocutionary acts used in the slogan of the airlines found in online advertising. An illocutionary act is a complete speech act made in a typical utterance, that consists of the delivery of the propositional content of the utterance (including references and a predicate), and a particular illocutionary force whereby the speaker asserts, suggests, demands, promises, vows, etc. (Searle and Vanderveken, 1985, p. 2). 
This research aims to describe how Illocutionary acts are used in the slogan of online airline advertising. In particular, the research objectives are : 1) to classify the illocutionary acts used in the slogans airline slogans found in online advertising based on Searle's illocutionary act division theory; 2) to describe the contextual meaning of illocutionary acts used in the airline slogans found in online advertising, and 3)to discover the most dominant illocutionary acts used in the airline slogans in online advertising.

\section{THEORETICAL FRAMEWORK}

\section{Contextual Meaning}

According to Leech (1983), context is any background knowledge or information assumed to be shared by speaker and hearer and which contributes to hearer's interpretation of what the speaker means by a given utterance. The context of an utterance is regarded as a function from a context (including time, place, and possible world) into a proposition, where a proposition is a function from a possible world into a truth-value. Context involves the interaction between an expression's context of utterance and the interpretation of what speaker says within that expression.

Further, Cutting (2002) divides context into three types. The first type is situational context which is what a speaker knows what he/she can see in the surrounding. The second type is the background knowledge context which is what a speaker and hearer know about each other and the world. The last is co-textual context which is what he/she knows about what he/she has been saying.

The background knowledge context and cotextual context are applied in this research to understand the contextual meaning of the slogans.

\section{Illocutionary Act}

Illocutionary acts are considered the core of the theory of speech acts. An illocutionary act is the action performed by the speaker in producing a given utterance. Illocutionary act is closely connected with speaker's intentions, e.g. stating, questioning, promising, requesting, giving commanding, threatening and many others (Yule, 1996, p. 48).

Illocutionary act is the making of a statement, offer, promise, etc., in uttering a sentence, by virtue of the conventional force associated with it (Levinson, 1983, p. 236). In general, illocutionary act consists of an illocutionary force and propositional content. The illocutionary force of an utterance is the speaker's intention which consisting many aspects in producing the utterance and the propositional content is something that becomes the speaker's assumption before stating the utterance (Searle and Vanderveken, 1985, p. 1).

Searle (1969) sets up the following classification of illocutionary speech acts, namely:

\section{Assertive}

Assertive is a type of illocutionary act that ties its speaker to the proposition of the utterance, for example: claiming, informing, and stating. The example below illustrates the use of an informing assertive illocutionary act: "It is raining".

\section{Expressive}

Expressive is a type of illocutionary act that indicates the speaker's feeling, attitude or the psychological state of the speaker, for example: apologizing, greeting and thanking. An example of a greeting expressive illocutionary act is: "Good morning".

\section{Directive}

Directive is a type of illocutionary act that is used to direct the listener to do something that is wanted by the speaker, for example: asking, ordering and requesting. An example of a requesting directive illocutionary act is: "Please bring me the salt".

\section{Commissive}

Commissive is a type of illocutionary act that ties the speaker to a commitment in the future, for example: promising, rejecting and threatening. An example of a promising commissive illocutionary act is: "I promise to be at school before five o'clock". 


\section{Declarative}

Declarative is a type of illocutionary act that affects immediate changes in the institutional state of affairs and which tends to rely on elaborate extra-linguistic institutions. The speaker should have authority to create a particular utterance in the suitable context, for example: declaring a war, christening, firing from employment. An example of a declarative illocutionary act is when a president of a country said, "Now, we are in the condition of war with this country".

\section{Advertising Slogan}

Advertising means informing a large number of people about something (Janoschka, 2004). It means a thing shown or presented to the public to help the copywriter or company sell a product, service and make an announcement.

A slogan, sometimes called a tagline (Granat, 2003), is an image or a sign of company. It is a phrase that comes and goes with particular lines of products on all its advertisement (Goddard, 1998, p. 105). It has two main purposes. The first is to provide continuity to a sequence of advertising in a campaign and represent a company's vision, and the second is to reduce an advertising message strategy to a brief, repeatable, and memorable positioning statement (Arens et al., 2012, p. 45). Slogans are used in both traditional and modern advertising. Slogans are also used to summarize the advertising idea to the consumers.

\section{METHODS}

The data for this research were collected from online advertisements. Altogether, a total of 40 advertising slogans were collected. The procedures for data collection and analysis were as follows:

1. Airline advertisements available online were observed from November 2015 to February 2016, and a total of 40 airline slogans were and collected.

2. News reports and official company websites were consulted to obtain important and relevant information about the products/ services being advertised in the advertise- ments to better understand the contextual meanings of the slogans in the advertisements.

3. Searle's taxonomy of illocutionary acts were adopted to analyze and classify the illocutionary acts found in the advertising slogans.

\section{RESULTS AND DISCUSSION}

Out of the 40 airline advertising slogans, most (28 occurrences or $70 \%$ ) belong to the category of assertive entailing expressive illocutionary acts. This category outnumbers the next frequently found category, that is, directive entailing expressive illocutionary acts (8 or $20 \%$ ). Only three slogans $(7.5 \%)$ belong to the category of commissive entailing expressive illocutionary acts, and only one slogan (2.5\%) belongs to the expressive category. No slogan was used to express the declarative illocutionary act. Table 1 below summarizes the results of the data analysis.

Table 1. Frequency and distribution of illocutionary acts in airline advertising slogans

\begin{tabular}{|c|c|c|c|}
\hline No & Illocutionary Acts & $\mathbf{n}$ & $\%$ \\
\hline 1 . & Assertive & 28 & 70.0 \\
\hline 2 . & Directive & 8 & 20.0 \\
\hline 3. & Commissive & 3 & 7.5 \\
\hline 4. & Expressive & 1 & 2.5 \\
\hline \multirow[t]{2}{*}{5.} & Declarative & 0 & 0 \\
\hline & Total & 40 & 100 \\
\hline
\end{tabular}

Note:

$\mathrm{n} \quad$ : number of occurrences

$\%$ : percentage

Out of the 28 assertive category, 15 (54\%) were claiming speech acts, 6 (21\%) were informing speech acts, 4 (14\%) notifying speech acts, 2 (7\%) assuring speech acts, and 1 (4\%) reminding speech act. It is clear that claiming speech acts were used much more frequently than other speech acts, which is in line with the fact that the slogans are used to persuade people to buy the advertised products or services. Claiming is closely connected to the notion of the speaker's right. As competition for winning people's approval is getting tighter, the advertising 
companies wish to be seen better than the others; which explains why the claiming speech acts were the most frequently used.

Informing speech acts were the second most frequently used when companies are promoting new features in their products, i.e. new routes and new planes. They use slogans to inform their target customers. Informing speech acts are also used to transform such information as becoming a member of an airline group or safety control official information. Reminding, notifying, and assuring are also used to make the customers know about the company's offers and then to persuade the customers by revealing new features or promotion.

In the following subsections, each of the categories is discussed in more detail.

\section{Assertives}

The assertive illocutionary act is one type of illocutionary acts, which commits the speaker in varying degrees, to the truth of the proposition expressed such as informing, notifying, claiming, reminding, etc. According to Searle (1976), the assertive category deals with true-false dimension, which means the utterance of the slogan, represents either truth or falsity. Below is an example of an airline advertising slogan advertised by Garuda Indonesia Airlines (www.bumn.go.id/ garuda), which expresses an assertive illocutionary act.

\section{(1) The Airline of Indonesia \\ (by Garuda Indonesia Airlines)}

The phrase "of Indonesia" in the slogan, which is preceded by "The Airline" means that the Airline (Garuda Indonesia) is representative of Indonesia. The phrase can be regarded as belonging to the informing assertive illocutionary act. To inform means asserting something, i.e., Garuda Indonesia is the airline that represents Indonesia, to the hearers (customers). Even though the target customers may, in fact, have known that Garuda is an airline representing Indonesia, it is important to make the information official. Official information also prevents ambiguity about the company's name (which contains the word "Indonesia"). Therefore, this slogan can be classified as an assertive.
Furthermore, the slogan "Airline of Indonesia" also indicates an expressive illocutionary act. There are many airline companies in Indonesia, but only Garuda Indonesia is named as the state flag-carrier. This means that Garuda Indonesia emphasizes its good quality service for its customer and the prestigious status of a representative of Indonesia. It implies that Garuda Indonesia is expressing its pride, thus, this slogan carries a boasting expressive illocutionary act.

In terms of its contextual meaning, this slogan informs the target customers that Garuda Indonesia is the representative of Indonesia. Many airlines in the world compete with one another to be acknowledged as the representative of their country (flyingblue.com.). For that reason, Garuda Indonesia uses its status as the Indonesian flag-carrier as a way to show its superiority to win the competition. In other words, Garuda Indonesia has privileges accorded by the government for international operations. Using "The Airline of Indonesia" Garuda Indonesia is showing the customers that they have those advantages as the flag-carrier airline.

Another example is a slogan found in an advertisement by Midwest Airlines (advertised on planetbuzz.com).

\section{(2) The Best Care in the Air (by Midwest Airlines)}

The slogan "The Best Care in the Air" carries an assertive illocutionary force that is an indicator of the assertive class. The illocutionary force of the assertive is the word "Best". This word is connected to the notion of setting or representing the speaker's belief that the company's service could be the best service and it ensures to provide benefit for the hearer. According to Merriam Webster dictionary, the definition of "best" is better than all others in quality or value, most productive of good: offering or producing the greatest advantage, utility, or satisfaction. From this definition, it can be concluded that the speaker (company) tries to inform the target customer that its products/ services are the greatest products on the market. It matches with "claim", an assertive illocutionary 
act. "Claiming" always has a connection with the speaker's notion.

The assertive is an illocutionary act whose purpose is to convey information about some state of affairs of the world from one agent, the speaker, to other agent, the hearer. The company tries to describe its product or service through the phrase "The best" which is followed by "the care in the air". It concludes that the company is trying to persuade its customers by informing what level of service they would get from the company. Therefore, the phrase: the best care in the air, is a slogan from Midwest which can be classified into Assertive because the speaker has claimed a thing (the best care), and there is no proof of it and claim only need a belief from one side, the speaker (company).

Moreover, the use of the phrase "The Best" in this slogan carries not only an assertive illocutionary act, but also an expressive illocutionary act, which portrays the company's pride. It seems that the speaker (company) considers that the product has the best quality in "Care" compared to the other companies. "The Best Care in the Air" matches with "boast", and is classified as an expressive by Searle (1976).

In line with Searle and Vanderveken (1985), "boast" expresses too much pride in oneself. It fits with this slogan, because the company is expressing its feelings and attitudes toward the quality of its product: serving the best flight service to the customers. It does not matter whether the slogan "The best care in the air" is true or not.

The context of the word "care" in "The Best Care in the Air" is about "Airplane service". Airplane services covers services from the company during the flight and other facilities offered such as new armada, new routes, etc. There is no need to argue that many low-fare airplanes are cutting down ticket prices together with the reduction of the services or facilities. Reducing the service means cutting the customer's comfort. For instance, to reduce cost and improve the capacity of a flight, many airlines are decreasing the space among its passengers. Accordingly, there is no space left and it will make the passengers uncomfortable.
Based on that problem, Midwest Airlines tries to be different from other airline companies. As reported on planetbuzz.com, the company tries to offer better services by providing low-fare ticket without reducing passengers' comfort to target customers through its slogan. Midwest Airlines expects that it will persuade its target customers to fly with the airline. Midwest Airlines believes that the best services will also have impact on the customer's experience and it can be seen when the company provides its passengers with impeccable service and onboard amenities at competitive fares. With the phrase "The best" in its slogan, Midwest emphasizes an effort from the company to convince its customer that the company provides many advantages i.e. lower fare ticket than any other companies do.

\section{Directives}

A directive speech act is a speech act produced by a speaker to make the hearer do something for the speaker. Belonging to this class are commanding, requesting, inviting, suggesting, etc. This class has a common preparatory condition, that is, the hearer is capable of doing what he is directed to do. Related to this research, directives create reason for the hearer (target customers) to do an action that the company directs them to do. The intensity of the speaker's desire about making the hearer do the directed act is low because there is no degree of authority between the speaker (company) and the hearer (customers). It may be impossible to find a directive using speaker's authority or power over the hearer such as ordering or commanding. Below is an example of the use of the directive speech act found in the airline slogan by Go Air India (www.goair.in).

$$
\begin{aligned}
& \text { Fly Smart } \\
& \text { (by Go Air India) }
\end{aligned}
$$

The slogan "Fly Smart" contains two words "Fly" and "Smart". The slogan is a "request" to the customers to fly "smart" with the company because it offers many facilities. The word "Smart" is intended to convince the consumers that if they choose the company's product and service, they are smart. This slogan is classified as a directive, because the hearers (target customer) could accept or reject the "request" to be "smart". 
This directive illocutionary act is not a strong command to the target customers as a strong command would be too offensive in advertising. The directive should be understood as a polite request. This means that if the customers believe in what the company offers to them, they could simply use the service, but if they think that the slogan "Fly Smart" does not have any truth in it they could simply refuse it.

Besides being a directive, "Fly Smart" also indicates the company's pride. The company is confident that the customers will get the quality service as well as low cost fares. This defines the slogan into a "boast". Boasting expresses pride with a presupposition that the offer is good for the speaker. Therefore, this slogan carries an expressive illocutionary act.

"Fly smart" is a slogan from Go Air India which promotes the facilities that the company has been offering. Go Air wants its target customers to be smart when choosing an airline to fly. The company states that Go Air is the best choice since Go Air is providing many "smart" advantages compared to other airlines.

As mentioned in www.goair.in, the slogan has been publicized in the same time with the launching of a new on board facilities, such as on board entertainment in which the passenger will be served with an LCD television with many channels. With these facilities, the company believes that the passengers will not get bored. Another new facility is in-flight experience which provides fresh food for the passengers. If any other companies offer their passenger food packed before the flight, Go Air India would cook the passenger's food in flight. The company guarantees that the food is fresh. This facility also gives the passengers opportunities to select food by themselves.

\section{(4) Widen Your World}

(by Turkish Airlines)

The word "widen" in "Widen Your World", according to Merriam Webster Dictionary, means increasing the width, scope, or extent of. The word "widen" is an imperative word, meaning a verb which creates or gives an order. Then, the word order in this phrase is the indicator of a directive as it is completed by the phrase "Your
World" to be an imperative phrase. From the context, the company (Turkish Airlines) is requesting its customers to extend their world. The phrase "Widen Your World" can be seen as a "request" from the company to travel from the place where they are now to other places by airplane. This illocutionary act embodies an effort on the part of the speaker to get the hearer to do something, to 'direct' him or her towards some goals (flying using the company's service). It can be concluded that the company, through the slogan, wants the customer (hearer) to use its product. The word "widen" is the indicator of a direct "request" then combine with the noun phrase "your world". Then the words become the slogan "widen your world". It is clear that the slogan carries a requesting directive illocutionary act.

For a better understanding, the phrase "Widen your world", can be paraphrased, based on the context and with the same propositional content and illocutionary force, as "Let's go travel with our company beyond your ordinary daily life". After understanding the proposition, the context, and based on the choice of the word "widen" and the phrase "your world", it could be inferred that the speaker believes that it is better for the hearer (customer) to widen their world by traveling with the company. Since the company seems to be so proud of its company product, it is a 'boast', which belong to the boasting expressive category.

An airplane is a means of transportation to move people from one place to another. As mentioned in turkishairlines.com, in the slogan, "Widen your world", Turkish Airlines is requesting its customers to move from the place where they are now to another place. "Your world" is defined as the place where we live. With the slogan, Turkish Airlines directly asks its customers flying with Turkish Airlines. Then, The company will make the customers visit many different places (world) like going beyond their expectations, and also deliver a travel experience that is different than before.

In brief, Turkish Airlines, through this slogan, attempts to persuade people to use its services. With new routes having been offered by 
the company, people could go anywhere and discover many new things. It can be said that the contextual meaning of "Widen your world" is whenever people are ready to seek new opportunity to see a new perspective or land, Turkish Airlines is ready to take them there.

\section{Commissives}

A commissive is a speech act, the purpose of which is to commit the speaker to carry out some action or to bring about some state of affairs. Since commissives deal with future action of the speaker, the proposition must represent some future course of action by the speaker, such as promising, accepting, guarantying, etc. In short, a commissive expresses a strong intention of the speaker in which he will commit future action. The following is an example of an airline slogan expression a commissive illocutionary act found in an advertisement on www.labbrand.com.

\section{Our Sign is a Promise}

(by Swiss Air)

In the slogan "Our Sign Is a Promise", the word "Promise" indicates a commissive illocutionary act. A promise is always made to a hearer to do something for his benefit (Searle and Vanderveken, 1985, p. 192). It is clearly seen that in this slogan, the company tries to persuade its customers to use the service by promising them that Swiss Air's product will be as good as what they can expect. Another pattern of a commissive illocutionary act is that the slogan involves a special commitment or obligation. This obligation is a promise which has the strength of a commitment.

With these two indicators, "Our Sign is a Promise" is an effort from the Swiss Air in which the company promises that it would deliver a better service since it has launched a new slogan and logo ("Our Sign"). Thus, this slogan expresses a commissive illocutionary act.

Furthermore, the slogan "Our Sign Is a Promise" also expresses a "boast", since boasting is expressing the pride with the propositional content that the thing speaker boasts about is good to the hearer. In this slogan, it can be seen when the company uses the phrase "Our Sign" to express its pride and to make the customers believe that the offered service is beneficial.

A "boast" makes the speaker brag about himself and about his accomplishments and often to impress others and value himself in front of the target speaker (Searle and Vanderveken, 1985, p. 215). This slogan can be classified as an expressive illocutionary act as long as the company is very proud of its product portrayed in the slogan.

As stated in the official website of Swiss Air, Swissair.com, the new slogan will be rounded off by a new statement in which the company has distilled their quality aspirations and their commitment to their customers into a few simple words. The word "sign" comes together with a new slogan logo, which means Swiss Air has undergone a transformation.

With this slogan, the company assures the readers (customers) that it will make many improvements in its service. One of them is the company will do more communication with its customers, so that the target customers are seen and felt. Swiss Air will treat the customers with a personal touch and character. "Our Sign is a Promise" is a promise from Swiss Air to be a better airline expressed by the new slogan-logo.

Here is another example of an airline slogan found on www.aidforum.org.

\section{You Name It, We Fly It} (by Cargo Lux)

The phrase "You Name It" has a propositional content identified as a request from the company to its customers: just name the items to be transported by airplane. It offers freedom to the target customers for shipping whatever they want to transport. The second phrase "We Fly It" refers to the action of the company to fulfill the customers' wish. "You name it, we fly it" is a promise from the speaker that is conditional on the hearer's acceptance (Searle and Vanderveken, 1985, p. 192). In other words, the speaker (company) will perform an act after getting the hearer's acceptance.

It can be concluded that this slogan contains a commissive illocutionary act, a type of illocutionary acts that commits the speaker to some future course of action (Searle, 1976). There 
should have an obligation which is created from the speaker's side, not in the hearer.

In addition, "You name it, we fly it" means that the company offers to its customers a simple, fast process of moving item by airplane. The indicator of the expressive act is a "boast". Having excellent facilities, crew, and the management system, Cargo Lux is confident to make its customers satisfied with the offer.

Cargo Lux (cargolux.com) has established itself as a high quality and a reliable air cargo carrier which offers a service of moving items from one place to another. Cargo Lux transports such items as live animals, perishables or outsized freight. The company tries to convince its customers a guarantee that the company is highly trained and has dedicated staff. It gives the company the best possible handling of the customers' shipments.

By this slogan "You Name It, We Fly It.", Cargo lux offers many advantages that may not be offered by other cargo carriers. They can carry almost everything. In a regular airline service, a company only allows the passenger to carry limited items. Although some airlines allow the passengers to carry many items, they have a strict rule that makes the passengers go through a complicated procedure to obtain a permission letter, while most airlines do not allow passengers to take their animals along. With all these conditions, Cargo Lux offers an easier way to transport the passenger's items.

\section{Expressives}

The expressive illocutionary act is a type of illocutionary acts which express the psychological state specified in the sincerity condition about a state of affairs specified in the propositional content. Expressives are used to state the speakers' feelings. Even though it has no direction of fit, the psychological state of expressives carries a belief and desire; the speakers believe in and desire something. Expressives are entailed in every type of illocutionary acts. As the speaker makes an utterance, there are always psychological states from the speaker in an utterance. The following is the one airline slogan found in an advertisement on www.emirates.com expressing an expressive illocutionary act.

\section{(7) Hello Tomorrow}

(Emirates Airlines)

The slogan "Hello Tomorrow", belongs to the expressive category. It does not contain any other illocutionary act other than an expressive act. The first word from this slogan, "Hello", is a common English word used for greeting. "Hello Tomorrow" can be defined as a "greeting" from the company (speaker) to its target customers (hearers).

"Greet" is only marginally an illocutionary act since it has no propositional content. When one greets someone else, one indicates recognition in a courteous fashion. We might define greeting as courteous indication of recognition, with presupposition that the speaker has just encountered the hearer (Searle and Vanderveken, 1985, p. 215). Thus, it is clear that the slogan can be classified as an expressive illocutionary act.

The slogan from Emirates has only two words, "Hello" and "Tomorrow". The purpose of the slogan is to make everyone remember for something unknown and about a place that has never been discovered. Aiming for customers who want to explore and discover the world that they have never been to, Emirates uses this slogan to express the company's assumption of discovering and exploring new places. It will help passengers experience different cultures, and meet new people they would probably like. With this slogan, Emirates expresses its concern to become the transportation for the passengers, connecting them to their new adventure "Tomorrow".

\section{CONCLUSION}

The present research examines illocutionary acts expressed in airline slogans found in online advertisements. The contextual meaning of the 40 slogans is about informing an offer from the company to its target customers. In some data, the contextual meaning of the slogans is an official information from the company, and also revealing the vision of the company.

Most the slogans express the assertive illocutionary acts. Assertives were found to be the 
most frequently used type of illocutionary acts in the advertisement because the companies intend to persuade their target customers to buy their products and/or services. They use assertives to convey information to their customers about, for example, their new facilities and new routes.

Furthermore, claiming is an assertive illocutionary act which is used most frequently by the companies. It occurs when the slogans are used to inform the customers, as well as to compete with the other companies. It can be concluded that to make the customers pay attention to their slogans, the companies offer better quality products and services even though there is no guarantee that what they claim is true. Thus, "Claiming" becomes the most frequently used assertive illocutionary act in the airline slogans under investigation. Following in the second place is the assertive illocutionary act of informing, and the third is assertive illocutionary act of notifying.

\section{REFERENCES}

Arens, William, et al. (2012). Contemporary Advertising and integrated marketing communications. New York: McGraw-Hill Education.

"Cargolux is Europe's biggest all-cargo airline with a fleet of modern Boeing 747-400 and 747-8 freighters." About Company. Cargolux Official Website. Web. 5 March 2016.

Cutting, Joan. (2002). Pragmatics and Discourse: $A$ Resource Book for Students. London: Routledge.

"Flag-carrier." Merriam-Webster.com. MerriamWebster, 2015.
"Food for a Maharajah now at your table." Inflight Experience. Go Air Official Website, 10 Dec 2015. Web. 12 March 2016.

"Garuda Indonesia is the flag carrier of Indonesia and serves as a full service airline."Garuda Indonesia. Flyingblue.com. Web. 12 March 2016.

Goddard, Angela. (1998). The language of Advertising. London: Routledge.

Granat, Jay. (2003). Persuasive Advertising for Entrepreneurs and Small Business Owners. Jakarta: Kencana.

Janoschka, Anja. (2004). Web Advertising. Philadelphia: John Benjamin Publishing Co.

Leech, G. (1983). Principles of Pragmatics. Harlow: Longman,

Levinson, S.C. (1983). Pragmatics. Cambridge: Cambridge University Press.

Searle, J. R. (1974). Speech Acts: An Essay in the Philosophy of Language. Press Syndicate of the University of Cambridge.

Searle, J. R. (1976). A Classification of Illocutionary Acts. Cambridge: Cambridge University Press.

Searle, J. R. and Vanderveken, D. (1985). Foundation of Illocutionary Logic. Melbourne: Cambridge University Press.

"Smart." Merriam-Webster.com. MerriamWebster, 2015.

Yule, George. (1996). Pragmatics. Oxford: Oxford University Press. 